\title{
Article \\ Ozonation of Amoxicillin and Ciprofloxacin in Model Hospital Wastewater to Increase Biotreatability
}

\author{
Severina Aleksić ${ }^{1}$, Andreja Žgajnar Gotvajn ${ }^{2}{ }^{(\mathbb{D}}$, Katarina Premzl ${ }^{3}$, Mitja Kolar ${ }^{2, *}$ (1) and Sonja Šostar Turk ${ }^{1, *}$ \\ 1 Faculty of Health Sciences, University of Maribor, Žitna ulica 15, SI-2000 Maribor, Slovenia; \\ severina.aleksic@leone.si \\ 2 Faculty of Chemistry and Chemical Technology, University of Ljubljana, Večna pot 113, \\ SI-1000 Ljubljana, Slovenia; andreja.zgajnar@fkkt.uni-lj.si \\ 3 National Laboratory of Health, Environmental and Food, Prvomajska ulica 1, SI-2000 Maribor, Slovenia; \\ katarina.premzl@nlzoh.si \\ * Correspondence: mitja.kolar@fkkt.uni-lj.si (M.K.); sonja.sostar@um.si (S.Š.T.); \\ Tel.: +386-1-479-8694 (M.K.); +386-2-30-04-705 (S.Š.T.)
}

\begin{abstract}
Amoxicillin (AMX) and Ciprofloxacin (CIP) are antibiotics commonly used in human medicine with high environmental toxicity and poor biodegradability. They have been found in various hospital effluents and groundwater, and their environmental impact is still not fully understood. In this work, we investigated the possibility of treating model wastewaters containing the antibiotics AMX and CIP using ozonation, with the addition of $\mathrm{H}_{2} \mathrm{O}_{2}$ under various conditions, including different $\mathrm{pH}$ values, $\mathrm{H}_{2} \mathrm{O}_{2}$, and ozone dosages. The quantification of and treatment efficacy for antibiotic removal were determined via solid phase extraction followed by chromatographic separation by liquid chromatography coupled with tandem triple quadrupole mass spectrometry (LC/MS/MS). This analytical system is quite efficient for the detection of all major antibiotic classes, even if they are present at very low concentrations. The efficiency of ozonation was determined by measuring the TOC (Total Organic Carbon) changes after ozonation of the model wastewater and by measuring the concentration of the two antibiotics. In a sequential activated sludge process of ozone-treated model wastewater, almost complete TOC removal and an overwhelming decrease in antibiotic concentrations (up to 99\%) were observed. Ozonation resulted in complete removal of AMX and CIP in less than 30 and 120 min, respectively. The results of this work indicate that ozonation could be a suitable pretreatment method to reduce the toxicity of contaminants (AMX and CIP) and improve the biodegradability of hospital wastewater.
\end{abstract}

Academic Editor: Jie Fu

Received: 30 September 2021

Accepted: 10 November 2021

Published: 17 November 2021

Publisher's Note: MDPI stays neutral with regard to jurisdictional claims in published maps and institutional affiliations.

Keywords: amoxicillin (AMX); antibiotic; ciprofloxacin (CIP); hospital wastewater; hydrogen peroxide; ozone; sludge; treatment

\section{Introduction}

Ciprofloxacin (CIP) from the fluoroquinolone family and Amoxicillin (AMX) from the beta-lactams group are used as broad-spectrum antimicrobial agents in hospitals, households, and veterinary medicine to treat bacterial infections. These applications result in the significant contamination of wastewater and groundwater. Both substances can enter the environment through a variety of pathways, including human excreta, improper disposal of unused medications, industrial and hospital wastewater, and veterinary use. One of the most important sources of these substances is wastewater [1,2].

AMX and CIP are highly toxic and difficult to biodegrade. The treatment of wastewater containing antibiotics is very complex because these wastewaters contain not only antibiotics but also inorganic and organic compounds, which all together can inhibit the activity of microorganisms in wastewater treatment plants (WWTP). The inhibitory effect on microorganisms in WWTPs is mainly seen in conventional WWTPs that use the activated sludge process, biological filters, or membranes to treat wastewater. Conventional 
wastewater treatment plants are not primarily designed to treat biologically active substances; these are inadequately removed from the wastewater and, thus, enter the aquatic environment [1,2].

Therefore, the removal of CIP in different types of biological treatment plants, e.g., activated sludge and rotating biological contactors, can reach up to $59 \%$ and $76 \%$, respectively. However, the final concentrations in treated wastewater are still problematic $\left(\mu \mathrm{g} \mathrm{L}^{-1}\right)$, as both CIP and AMX occur in the aquatic environment at concentrations up to $400 \mu \mathrm{g} \mathrm{L}^{-1}$ [3]. Although measured concentrations are generally many times lower than therapeutic doses and are not acutely toxic, little is known about the long-term effects on aquatic organisms. Moreover, previous reports have indicated that CIP and AMX may specifically trigger microbial communities in aquatic ecosystems, contributing to the development of resistant bacteria [4-6]. Therefore, much research effort has been made in the last decade to find efficient methods to remove these substances from wastewater. There are several methods that give promising results and belong to a group of AOPs (Advanced Oxidation Processes) [7,8].

AOPs rely on the formation of hydroxyl radicals $(\bullet \mathrm{OH})$, which can oxidize organic molecules in a strongly nonselective manner [5]. Recent studies show that AOPs can be successfully used for the treatment of pharmaceutical wastewater. Oxidation by Fenton and photo-Fenton processes could degrade Sulfamethoxazole very effectively [9]. The fate of pharmaceutical Diclofenac removal by photolysis and $\mathrm{H}_{2} \mathrm{O}_{2}$ enhanced photolysis has been reported $[10,11]$. The combined $\mathrm{UV} / \mathrm{H}_{2} \mathrm{O}_{2}$ process was also very effective in degrading Diclofenac [12]. Reverse osmosis, activated carbon, and ozonation have been shown to significantly reduce or eliminate antibiotics and pharmaceutical substances in wastewater. These processes use one or more oxidants, usually hydrogen peroxide and/or oxygen [12,13]. AOPs have the advantage of generally eliminating such contaminants through mineralization or conversion to products that are less harmful to human health and the aquatic environment [14].

Ozonation is one of the most efficient AOPs. Ozone and/or hydroxyl radicals passivate the bactericidal properties of antibiotics by impairing or modulating their pharmaceutically active functional groups, such as the N-etheroxime and dimethylamino groups of Macrolides [15]. High removal rates (90\%) were achieved by ozonating the compounds with electron-rich aromatic systems such as hydroxyl, amino (e.g., sulfamethoxazole), acylamino, alkoxy, and alkyl aromatic groups, as well as the compounds with deprotonated amine groups (e.g., erythromycin, ofloxacin, and trimethoprim) and non-aromatic alkene groups, since these structural components are highly modifiable for oxidative attack [16]. The ozonation process was found to be effective for the removal of beta-lactams, macrolides, sulfonamides, trimethoprim, quinolones, tetracyclines, and lincosamides [17].

However, due to the high concentrations and diversity of organic compounds in wastewater, mineralization of the active compounds is often incomplete [18], and such oxidized byproducts can lead to a significant increase in toxicity compared to the original compound [19]. Moreover, many studies only focus on degradation kinetics and degradation processes without determining toxicity. Very little is currently known about the transformation products, the specific reaction mechanisms, and the toxicity assessment of the transformation mixtures. These assessments are of considerable importance for environmental protection and wastewater treatment. Therefore, the primary objective of this study was to use an AOP (i.e., ozonation) with the addition of hydrogen peroxide to remove and inactivate high concentrations of CIP and AMX in model wastewaters. Such highly contaminated wastewaters are usually generated in small quantities, so ozonation seems to be a viable option for their treatment. The main advantage of combining ozone with hydrogen peroxide is the accelerated formation of $\bullet \mathrm{OH}$ and, thus, better oxidation of the active substances [20].

Since ozonation does not necessarily lead to complete mineralization of the antibiotic components, we also determined the concentrations of CIP and AMX as well as total organic carbon (TOC) before, during, and after ozonation to assess whether the components were 
completely degraded [21]. In addition, the toxicity to the activated sludge was monitored before and after the experiment to evaluate the possible production of toxic byproducts that could further affect the biological treatment plant.

A recent review found that this area is still of great interest because conventional wastewater treatment plants cannot effectively remove antibiotics. Moreover, the occurrence of antibiotics in wastewater is of concern worldwide. The most promising methods for treating antibiotics are ozone-based AOPs, as they are fast, non-selective, and effective [22-26].

In our previous work [27], we studied the removal of AMX and CIP from hospital wastewater by subcritical and supercritical water oxidation. We observed the effect of temperature and flow rate of the sample on the concentration of antibiotics. We concluded that the highest chemical oxygen demand (COD) and TOC removal was achieved at the highest temperature of $500{ }^{\circ} \mathrm{C}$, where it was reduced by $76 \%$ and $63 \%$, respectively. An additional toxicity test, measuring the respiration inhibition of the activated sludge, confirmed that the samples after subcritical and supercritical oxidation were less inhibitory than the initial solution. Despite the encouraging results, we concluded that this process is not suitable for industrial or commercial use due to the high investment and operating costs.

\section{Results}

\subsection{LC/MS Methodology/Optimization}

Chromatography of the selected antibiotics was tested on three different columns: ASCENTIS Express C18 $(50 \mathrm{~mm} \times 2.1 \mathrm{~mm}$ I.D., $2.7 \mu \mathrm{m})$, Synergie Fusion-RP $100 \mathrm{~A}$ $(50 \mathrm{~mm} \times 2.0 \mathrm{~mm}$ I.D., $2.5 \mu \mathrm{m})$, and Kinetex XB-C18 100 A $(50 \mathrm{~mm} \times 2.1 \mathrm{~mm}$ I.D., $2.6 \mu \mathrm{m})$. The shapes of the chromatographic peaks were comparable, although the peak intensity was about $20 \%$ higher on the Synergi Fusion-RP 100 column. The analysis of the compounds was therefore performed using a Synergie $2.5 \mu \mathrm{m}$ Fusion RP $100 \mathrm{~A}, 50 \times 2.0$ (Phenomenex, Germany), a polar end-capped C18 phase column (it contains high reproducibility and a stable phenyl phase), which improves the retention of highly polar and aromatic compounds. For optimal chromatographic separation and good peak shape, $0.1 \%$ formic acid was added to promote protonation of both compounds and increase sensitivity. The retention time of amoxicillin was $1.12 \mathrm{~min}$, while the retention time of ciprofloxacin was $7.08 \mathrm{~min}$. LOD (limit of detection) and LOQ (limit of quantification) values for ciprofloxacin were found to be $0.07 \mu \mathrm{g} \mathrm{L}^{-1}$ and $0.23 \mu \mathrm{g} \mathrm{L}{ }^{-1}$, respectively. LOD and LOQ values for amoxicillin were found to be $0.05 \mu \mathrm{g} \mathrm{L}-1$ and $0.15 \mu \mathrm{g} \mathrm{L}-1$, respectively.

The linearity of the method was checked daily by constructing a calibration curve at six concentration levels. Calibration curves were constructed from the measured areas of the chromatographic peaks by plotting the concentration ratio of the standards to the internal standard on the $x$-axis and the corresponding area ratio on the $y$-axis.

The linear calibration curves obtained for AMX and CIP are shown in Figure 1.

Figure 1 shows the calibration curve of AMX, ranging from 40 to $800 \mathrm{ng} \mathrm{mL}^{-1}$, and the calibration curve of CIP, ranging from 50 to $1000 \mathrm{ng} \mathrm{mL}^{-1}$. The calibration curves obtained between the average peak and concentration showed a linear relationship with a correlation coefficient of 0.9998 for both antibiotics, so the LC/MS method was found to be highly selective and reproducible. 


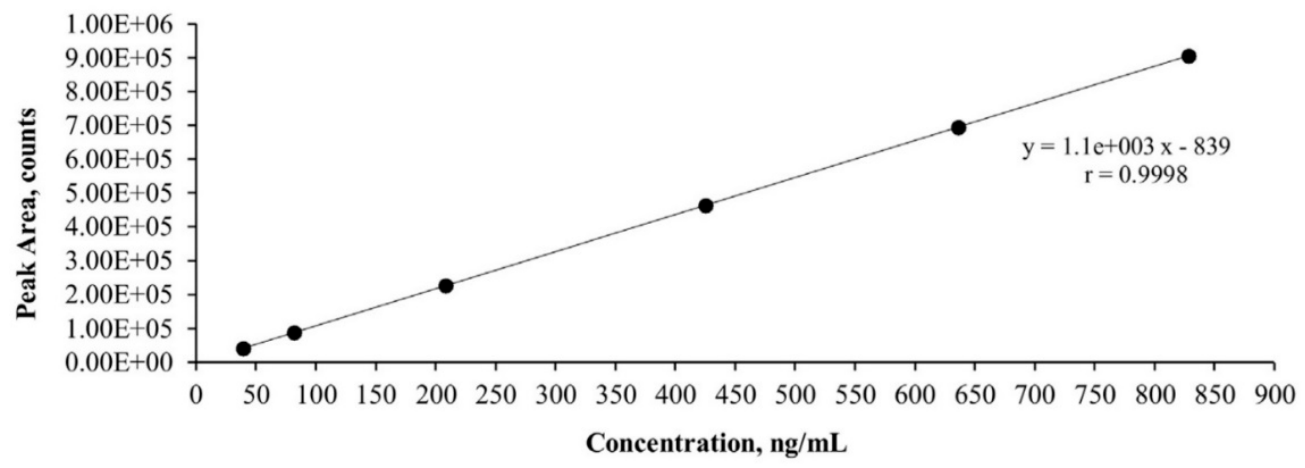

(a)

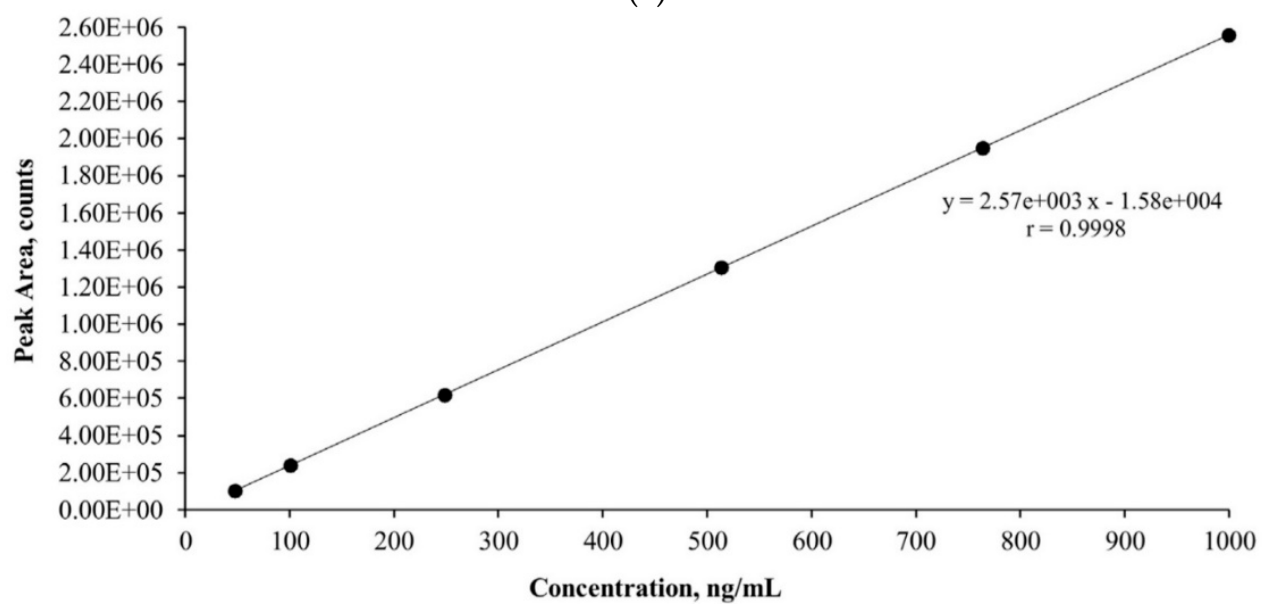

(b)

Figure 1. (a) Linear response of AMX. (b) Linear response of CIP.

\subsection{Amoxicillin and Ciprofloxacin Degradation}

The effectiveness of AMX and CIP ozonation was evaluated considering the influence of two variables: $\mathrm{pH}$ and the addition of hydrogen peroxide. Figure $2 \mathrm{a}_{1}, \mathrm{~b}_{1}, \mathrm{c}_{1}$ shows the TOC removal efficiency for model wastewater with AMX and CIP. It can be seen that alkaline conditions (Figure $2 b_{1}$ ) showed a higher removal efficiency compared to acidic conditions (Figure 2a $a_{1}$ ). The TOC removal efficiency was five times more efficient. As shown in Figure $2 a_{2}, b_{2}, c_{2}$, ozonation was effective in removing AMX and CIP from the model wastewater. For both CIP and AMX, degradation was most pronounced under alkaline conditions ( $\mathrm{pH}=10.85$ ), with the combined $\mathrm{O}_{3} / \mathrm{H}_{2} \mathrm{O}_{2}$ process achieving $99 \%$ removal efficiency for AMX and $95 \%$ for CIP. Regardless of the process conditions, the total concentration of CIP (Figure $2 a_{2}, b_{2}$ ) remained constant in all cases during the first $30 \mathrm{~min}$ (5000 $\mathrm{mg}_{\text {ozone }} \mathrm{mg}_{\text {antibiotics }}{ }^{-1}$ ), and then removal efficiency increased to $35.3-54.8 \%$ at an ozonation time of $60 \mathrm{~min}\left(10,000 \mathrm{mg}_{\text {ozone }} \mathrm{mg}_{\text {antibiotics }}{ }^{-1}\right)$, while the concentration of AMX increased to $78 \%$ at $60 \mathrm{~min}\left(11,059 \mathrm{mg}_{\text {ozone }} \mathrm{mg}_{\text {antibiotics }}{ }^{-1}\right)$ in acidic conditions and to $85 \%$ at $30 \mathrm{~min}\left(6179 \mathrm{mg}_{\text {ozone }} \mathrm{mg}_{\text {antibiotics }}{ }^{-1}\right)$ in alkaline conditions.

The addition of $\mathrm{H}_{2} \mathrm{O}_{2}$ also slightly accelerated CIP and AMX degradation (Figure $2 \mathrm{c}_{2}$ ). The efficiency of degradation of the compounds gradually increased with increasing $\mathrm{H}_{2} \mathrm{O}_{2}$ concentration. Figure $2 \mathrm{a}_{2}$ also shows that at $\mathrm{pH} 3.70$, the degradation of both AMX and CIP takes $120 \mathrm{~min}$ (22119 $\mathrm{mg}_{\text {ozone }} \mathrm{mg}_{\text {antibiotics }}{ }^{-1}$ and $20338 \mathrm{mg}_{\text {ozone }} \mathrm{mg}_{\text {antibiotics }}{ }^{-1}$, respectively) after receiving the same ozone dose. The difference occurs at a $\mathrm{pH}$ of 10.85 , where CIP degradation takes twice as long as AMX degradation.

It can be concluded that both acidic and alkaline conditions ( $\mathrm{pH} 3.70$ and $\mathrm{pH} 10.85$ ) increased the degradation efficiency. However, the concentrations of both antibiotics remained higher at $\mathrm{pH} 3.70$ than at $\mathrm{pH} 10.85$, and the removal of TOC was also more effective at $\mathrm{pH} 10.85$ than at $\mathrm{pH} 3.70$. 


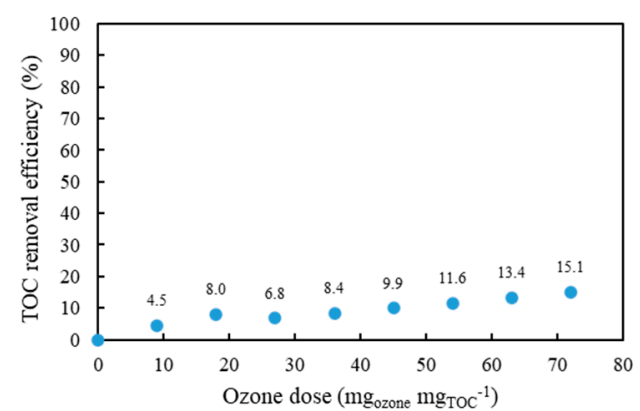

(a1)

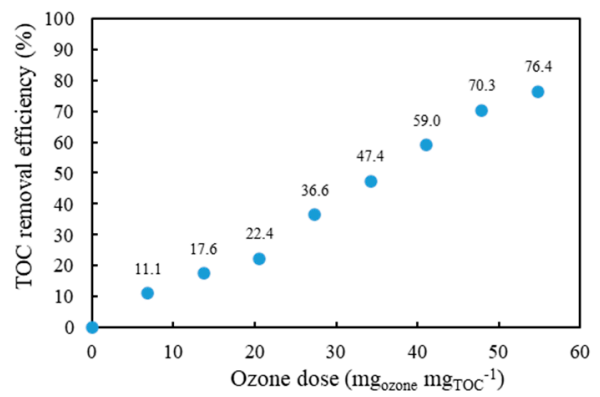

(b1)

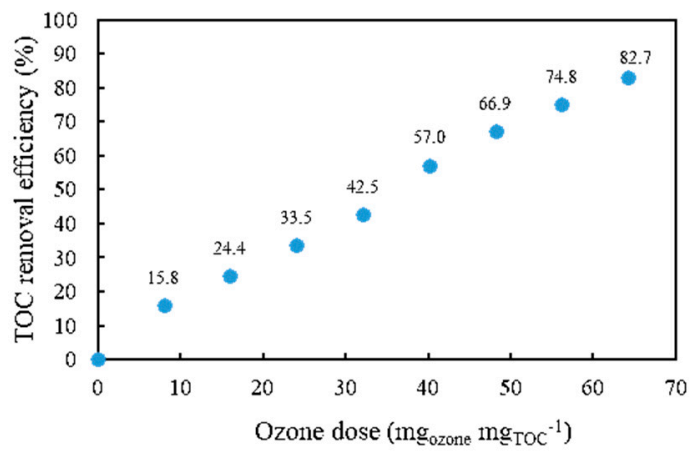

(c1)

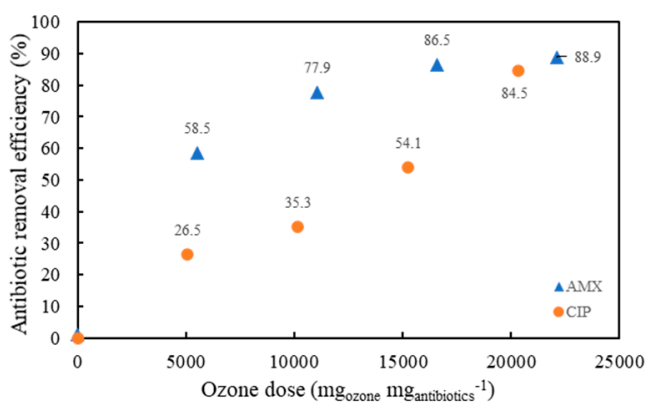

(a2)

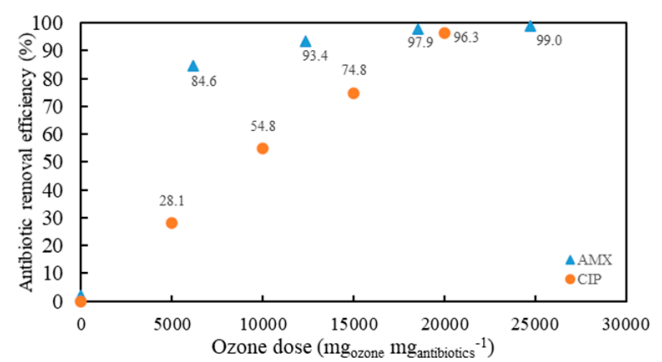

(b)

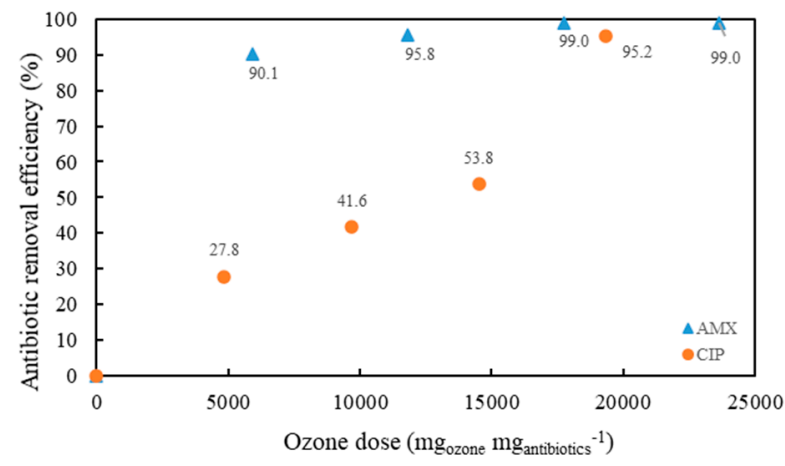

(c2)

Figure 2. TOC concentration of model wastewater $\left(\mathbf{a}_{1}\right)$ and AMX/CIP concentration at $\mathrm{pH}=3.70\left(\mathbf{a}_{2}\right)$. TOC concentration of model wastewater $\left(\mathbf{b}_{\mathbf{1}}\right)$ and AMX/CIP concentration at $\mathrm{pH}=10.85\left(\mathbf{b}_{\mathbf{2}}\right)$. TOC concentration of model wastewater $\left(\mathbf{c}_{\mathbf{1}}\right)$ and AMX/CIP concentration at $\mathrm{pH}=10.85$ with addition of $\mathrm{H}_{2} \mathrm{O}_{2}\left(\mathbf{c}_{2}\right)$.

\subsection{TOC Degradation}

Comparison of two different applied ozone gas flows resulting in two concentrations of ozone in gaseous phase (Figure 3) showed that the results are comparable. However, it can be seen that at an applied concentration of $100 \mathrm{~g} \mathrm{~L}^{-1}$ of ozone, $90 \%$ TOC was removed after $120 \mathrm{~min}\left(72 \mathrm{mg}_{\text {ozone }} \mathrm{mg}_{\mathrm{TOC}}{ }^{-1}\right)$, while at $55 \mathrm{~g} \mathrm{~L}^{-1}$, the removal efficiency reached only $70 \%$ after $120 \mathrm{~min}\left(43 \mathrm{mg}_{\text {ozone }} \mathrm{mg}_{\text {TOC }}{ }^{-1}\right.$ ).

In the next set of experiments, ozonation with the addition of $\mathrm{H}_{2} \mathrm{O}_{2}(0.01,0.02$, and $0.04 \mathrm{M}$ ) was studied (Figure 4).

As observed, TOC removal efficiencies increased with hydrogen peroxide concentrations of $0.02 \mathrm{M}$ and $0.04 \mathrm{M}$. 


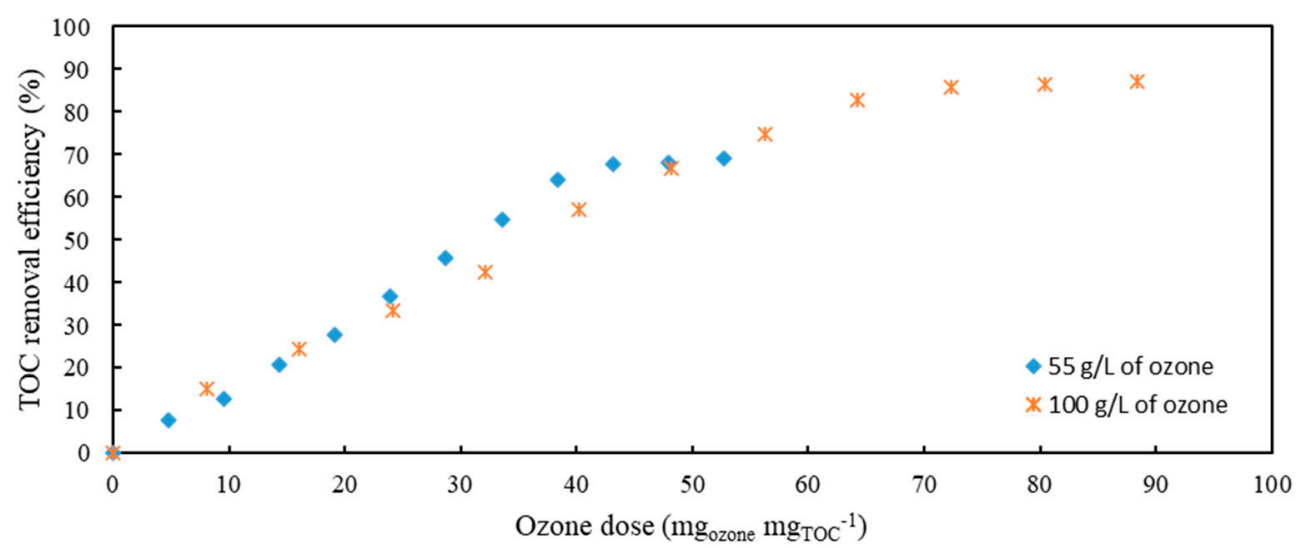

Figure 3. Comparison of different concentrations of ozone for ozonation of model wastewater containing AMX and CIP.

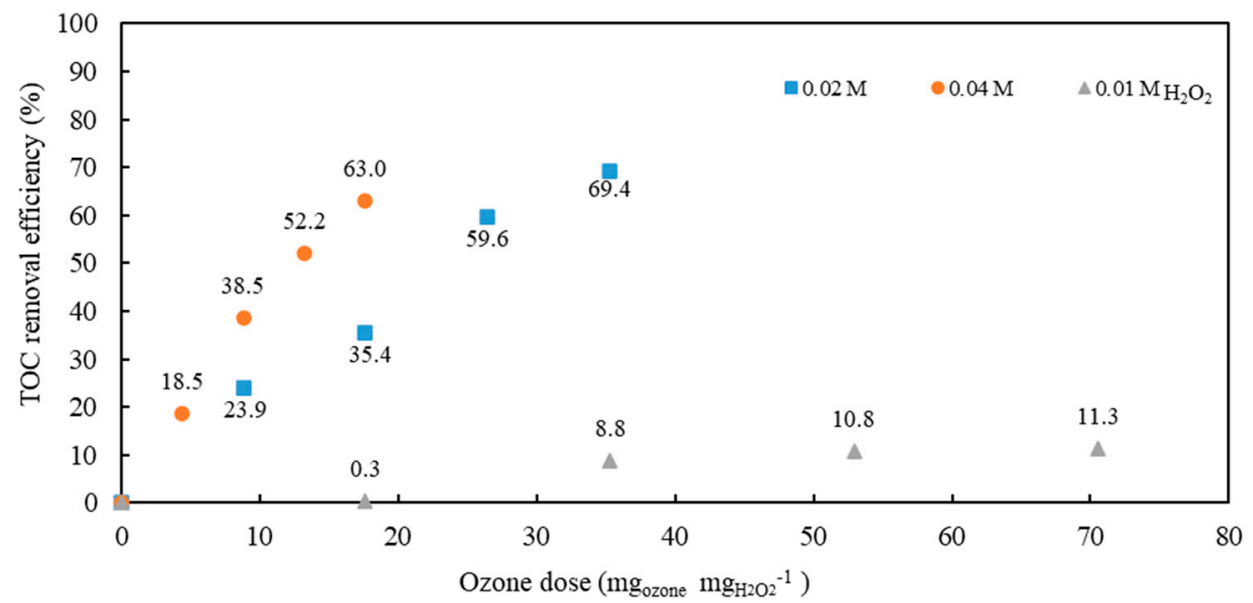

Figure 4. TOC removal efficiency at $\mathrm{pH}=10.85$ and different dosages of $\mathrm{H}_{2} \mathrm{O}_{2}$ in model wastewater containing AMX and CIP.

\subsection{Toxicity Test}

The toxicity of ozonated samples at $\mathrm{pH} 3.70$ and $\mathrm{pH} 10.85$ with and without the addition of $\mathrm{H}_{2} \mathrm{O}_{2}$ (model wastewater with both antibiotics) was evaluated (Figure 5).

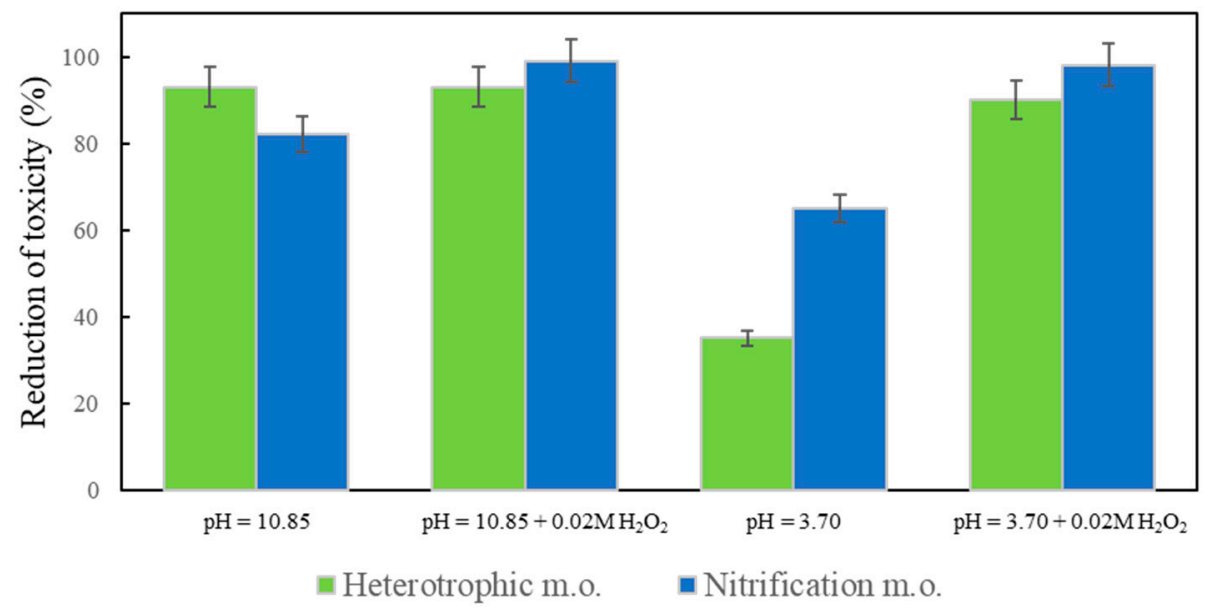

Figure 5. Reduction of toxicity of model wastewater after 120 min of ozonation at $\mathrm{pH} 3.70$ and 10.85 with and without addition of $0.02 \mathrm{M} \mathrm{H}_{2} \mathrm{O}_{2}$.

The toxicity was calculated as the relative reduction compared to the untreated model wastewater $(\%)$. After ozonation under different conditions, toxicity was always reduced; 
it had a very low effect on heterotrophic and nitrifying microorganisms of the activated sludge, confirming the deactivation of both antibiotics. To improve nitrification efficiency in biological wastewater treatment plants, it is very important to reduce the inhibition of nitrifying microorganisms, which are sensitive to antibiotics. Ozone and/or hydroxyl radicals passivate the bactericidal properties of antibiotics by interfering or modulating their pharmaceutically active functional groups [28].

\section{Discussion}

The extraction efficiency of the selected antibiotics was tested on three different SPE cartridges, and the results showed (data not shown) that the Oasis HLB cartridge gave the best results at a set $\mathrm{pH}$ of 7.00. Similar results have also been reported by other authors [29]. Based on these results and the corroborating literature $[30,31]$, the Oasis HLB cartridge (200 mg/6 mL) was selected for effluent monitoring. Then, LC/MS optimization was performed, where an external solution with diluted antibiotics was used for sample quality control. Detection was performed by multiple reaction monitoring (MRM) with positive electrospray ionization (ESI+).

The effectiveness of AMX and CIP ozonation was then evaluated. The acidic conditions favor a direct reaction of ozone, while the alkaline conditions support the formation of $\bullet \mathrm{OH}$ radicals, and thus, the oxidation of organic molecules proceeds much faster compared to systems with ozone alone [32]. Similarly, the addition of $\mathrm{H}_{2} \mathrm{O}_{2}$ prior to ozonation accelerates the formation of $\bullet \mathrm{OH}$ radicals, so the removal efficiencies may be comparable [33]. Despite different degradation rates during ozonation of model wastewaters, the studied antibiotics were almost completely degraded (more than $80 \%$ ). From the TOC measurements, it can be concluded that some byproducts still remained.

Similarly to previous studies [34], high pH values (>10) cause high efficiency of ozonation and rapid degradation of organic matter in wastewater due to the formation of highly reactive $\bullet \mathrm{OH}$ radicals (Figure $2 \mathrm{a}_{2}, \mathrm{~b}_{2}, \mathrm{c}_{2}$ ) [35]. In their study, Akmehmet and Ötker [36] applied ozonation to synthetic Penicillin wastewater. About $70 \%$ and $40 \%$ of the initial COD (450 $\left.\mathrm{mg} \mathrm{L}^{-1}\right)$ and TOC $\left(162 \mathrm{mg} \mathrm{L}^{-1}\right)$ were removed by ozonation after $1 \mathrm{~h}$ at an applied ozone dose of $2.96 \mathrm{~g} \mathrm{~L}^{-1}$ at $\mathrm{pH}$ values of 7.00 and 11.00 and a temperature of $20{ }^{\circ} \mathrm{C}$, respectively. As shown in our case, the removal of TOC (Figure $2 \mathrm{a}_{1}, \mathrm{~b}_{1}, \mathrm{c}_{1}$ ) was more efficient at higher $\mathrm{pH}$ values.

The role of hydrogen peroxide has been highlighted in several previous works-a high concentration of hydrogen peroxide accelerates the ozonation reaction and provides high contaminant removal efficiency. This was probably caused by both the self-decomposition of $\mathrm{H}_{2} \mathrm{O}_{2}$ into oxygen and water and the recombination of $\cdot \mathrm{OH}$ to $\cdot \mathrm{O}_{2} \mathrm{H}$, resulting in a higher oxidation efficiency [34,35].

The mechanisms of AMX degradation during ozonation have previously been described by Andreozzi et al. [10]. It was found that the reaction rate between AMX and molecular ozone is strongly $\mathrm{pH}$ dependent, from $4 \times 10^{3} \mathrm{M}^{-1} \mathrm{~s}^{-1}$ at $\mathrm{pH} 2.50$ to $6 \times 10^{6} \mathrm{M}^{-1} \mathrm{~s}^{-1}$ at $\mathrm{pH}$ 7.00. The ozone attack is mainly directed towards the phenolic ring, leading to the formation of hydroxyderivative intermediates. This was also confirmed in our study, as TOC was reduced less (69\%) than the concentration of antibiotics (90\%).

The mechanisms of CIP degradation during ozonation have previously been described by Demeestere et al. [37]. At pH 10.00, deprotonation of the N4'atom of the piperazinyl group enhanced direct ozonation at this site of the molecule. The addition of $\mathrm{H}_{2} \mathrm{O}_{2}$ to the CIP ozonation experiments at $\mathrm{pH} 7.00$ had limited effect on quinolone degradation and ozone and $\mathrm{H}_{2} \mathrm{O}_{2}$ consumption, suggesting that the radical chain mechanism is of lesser importance for quinolone degradation compared to direct ozonation. Identification of the degradation products showed the strongest degradation at the piperazinyl substituent at $\mathrm{pH} 10.00$, while degradation at the quinolone moiety at $\mathrm{pH} 7.00$ appears promising.

The mechanisms of these reactions have not been fully elucidated, and there is considerable disagreement in the literature as to the exact intermediates that are formed, including whether or not the hydroxyl radical is an intermediate [37]. 
Demeestere et al. [37] additionally performed a toxicity assay after the ozonation of CIP. The residual antibacterial activity against $P$. fluorescens and E. Coli appeared to be mainly determined by the rate of degradation of the parent compound. For B.coagulans, there was no difference in the reduction of antibacterial activity, although the fastest ozonation was achieved at $\mathrm{pH} 10.85$.

The literature on the removal of antibiotics by ozonation from heavily polluted wastewater is currently limited. Most ozonation experiments have been conducted under controlled conditions and with antibiotics dissolved in deionized water. For example, Najafpoor et al. [38] determined the efficiency of CIP removal using ozonation from aqueous solutions. The process parameters were studied with CIP concentrations of $10-50 \mathrm{mg} \mathrm{L}^{-1}$, $\mathrm{pH}$ of $3-12$, reaction time of $60 \mathrm{~min}$, and ozone concentration of $1.4 \mathrm{mg} \mathrm{L}^{-1} \mathrm{~min}^{-1}$ in a semiconductor reactor. The results showed that under optimal conditions $(\mathrm{pH}=12$ $\mathrm{O}_{3}=1.4 \mathrm{~g} \mathrm{~L}^{-1} \mathrm{~min}^{-1}$ and an initial antibiotic concentration of $\left.10 \mathrm{mg} \mathrm{L}^{-1}\right), 94.6 \%$ of CIP was removed. In our study, $1 \mathrm{mg} \mathrm{L}^{-1} \mathrm{CIP}$ was efficiently removed from the model wastewater at a higher $\mathrm{pH}(10.85)$.

Lefebvre et al. [39] studied the suitability of ozone pretreatment for AMX wastewater before biological treatment. They found that ozonation is not a suitable pretreatment for AMX containing pharmaceutical wastewater. De Witte et al. [40] studied the effect of $\mathrm{pH}$ on CIP degradation during ozonation of hospital wastewater. Degradation at $\mathrm{pH} 7.00$ increased the half-life of CIP to $29.1 \mathrm{~min}$, compared to $26.8 \mathrm{~min}$ at $\mathrm{pH} 3.00$ and $18.7 \mathrm{~min}$ at $\mathrm{pH} 10.00$.

Our results are in agreement with those of Zaviska et al. [41], who also showed that the combination of $\mathrm{H}_{2} \mathrm{O}_{2}$ and $\mathrm{O}_{3}$ produced a higher number of very reactive $\bullet \mathrm{OH}$ radicals and made the process more efficient. Due to the high cost of ozone generation, this combination also makes the process economically feasible [42].

\section{Materials and Methods}

\subsection{Chemicals}

Ciprofloxacin (analytical standard, 99.5\% purity, $\mathrm{C}_{17} \mathrm{H}_{18} \mathrm{FN}_{3} \mathrm{O}_{3}, 331.34 \mathrm{~g} \mathrm{~mol}^{-1}$ ), Amoxicillin trihydrate (analytical standard, 85.7\% purity, $\mathrm{C}_{16} \mathrm{H}_{19} \mathrm{~N}_{3} \mathrm{O}_{5} \mathrm{~S} \cdot 3 \mathrm{H}_{2} \mathrm{O}, 419.45 \mathrm{~g} \mathrm{~mol}^{-1}$ ), and Ciprofloxacin-D8 hydrochloride hydrate (99\% purity) were provided by Sigma-Aldrich, Fluka (Darmstadt, Germany). Amoxicillin ( $3 \mathrm{H}_{2} \mathrm{O}$ Phenyl-13C6, $\geq 95 \%$ purity) was obtained from USA Cambridge Isotope Laboratories (Andover MA, USA). All reagents were purchased in HPLC grade from Sigma-Aldrich, Fluka (Darmstadt, Germany) or Merck (Darmstadt, Germany). Hydrogen peroxide (30\% w/w, Ph.Eur., USP, pharmaceutical grade) was purchased from AppliChem, Darmstadt, Germany.

\subsection{Model Wastewater Preparation}

Synthetic standard wastewater (ISO OECD standard, 2004) was prepared from Solution 1 (containing urea $\left(30 \mathrm{~g} \mathrm{~L}^{-1}\right)$, sodium chloride $\left(\mathrm{NaCl}, 7 \mathrm{~g} \mathrm{~L}^{-1}\right)$, magnesium sulfate heptahydrate $\left(\mathrm{MgSO}_{4} \cdot 7 \mathrm{H}_{2} \mathrm{O}, 2 \mathrm{~g} \mathrm{~L}{ }^{-1}\right)$, and potassium dihydrogen phosphate $\left(\mathrm{KH}_{2} \mathrm{PO}_{4}\right.$, $\left.28 \mathrm{~g} \mathrm{~L}^{-1}\right)$ ) and Solution 2 (containing calcium chloride monohydrate $\left(\mathrm{CaCl}_{2} \cdot \mathrm{H}_{2} \mathrm{O}, 4 \mathrm{~g} \mathrm{~L}^{-1}\right)$ ). Then, $1 \mathrm{~mL}$ of Solution 1 and $1 \mathrm{~mL}$ of Solution 2 were mixed with $160 \mathrm{mg}$ of peptone in $1 \mathrm{~L}$ of deionized water. This mixture gives an average TOC concentration of about $78-82 \mathrm{mg} \mathrm{L}^{-1}$ and COD concentration of 356-386 $\mathrm{mg} \mathrm{L}^{-1}$. An appropriate volume of the mixture of the standard solution of Ciprofloxacin and Amoxicillin was added to the standard synthetic municipal wastewater to obtain a concentration of $1 \mathrm{mg} \mathrm{L}^{-1}$ of AMX and $1.2 \mathrm{mg} \mathrm{L}^{-1}$ of CIP.

\subsection{Ozonation Experiments}

The main experiment was set up to study the effect of ozone dosage on treatment performance. Ozone was generated from pure oxygen used as feed gas ( $>99.5$ vol. \%, Messer, Bad Soden, Germany) and was introduced at the bottom of the glass bubble column reactor (250 mL) (Figure 6) through a gas distributor using the Wedeco ozone generator (Xylem 
Water Solutions Herford GmbH, type OCS Modular 8 HC, Herford, Germany). The $\mathrm{O}_{3}$ generator used had a production capacity of $8 \mathrm{~g} \mathrm{~h}^{-1}$, with the possibility to control the gas flow at $\mathrm{Q}_{\mathrm{G}}=10-100 \mathrm{NL} \mathrm{h}^{-1}$ and to adjust the ozone concentration in the produced gas to $10-100 \mathrm{~g} \mathrm{Nm}^{-3}$. All gas phase flows $\left(\mathrm{Nm}^{-3}, \mathrm{NL}\right)$ were measured with scales of normal temperature $\left(0^{\circ} \mathrm{C}, 273 \mathrm{~K}\right)$ and pressure $(100 \mathrm{kPa})$ conditions.

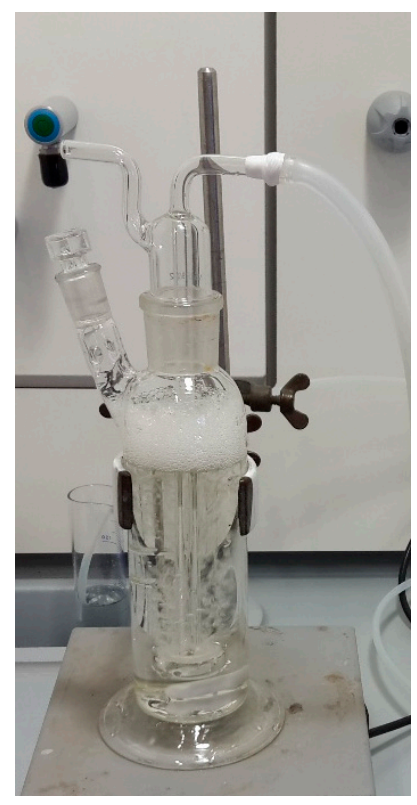

Figure 6. Glass bubble column reactor.

All ozonation experiments were conducted for $120 \mathrm{~min}$. At $t=0,15,30,45,60,75$, 90,105 , and $120 \mathrm{~min}, 5 \mathrm{~mL}$ of the sample was taken for determination of TOC, and at $t=30,60,90$, and $120 \mathrm{~min}$, the samples were analyzed for the concentrations of AMX and CIP. The experiments were performed in duplicate, and analyses were repeated three times. The experimental conditions with ozone doses are given in Table 1 below. Ozonation was performed under acidic conditions $\left(\mathrm{pH}=3.70\right.$, Table 1 , Value $\left.{ }^{1}\right)$ and alkaline conditions $(\mathrm{pH}=10.85)$ with (Table 1 , Value ${ }^{3}$ ) and without (Table 1, Value ${ }^{2}$ ) the addition of hydrogen peroxide.

Table 1. Experimental conditions.

\begin{tabular}{|c|c|c|c|c|c|}
\hline Parameter & Value $^{1}$ & Value $^{2}$ & Value $^{3}$ & Value $^{4}$ & Value $^{5}$ \\
\hline $\mathrm{pH}(/)$ & $3.70 \pm 0.10$ & $10.85 \pm 0.10$ & $10.85 \pm 0.10$ & $10.85 \pm 0.10$ & $10.85 \pm 0.10$ \\
\hline Applied $\mathrm{O}_{3}$ concentration $\left(\mathrm{mg} \mathrm{L}^{-1}\right)$ & 100 & 100 & 55 and 100 & 100 & 100 \\
\hline Applied $\mathrm{H}_{2} \mathrm{O}_{2}$ concentration $\left(\mathrm{g} \mathrm{L}^{-1}\right)$ & - & - & - & 0.68 & $0.34,0.68,1.36$ \\
\hline Ozone dose $\left(\mathrm{mg}_{\text {ozone }} \mathrm{mg}_{\mathrm{TOC}^{-1}}\right)$ & $0,18,36,54,72$ & $0,14,27,41,54$ & $0,9.6,19,28,8,38,53$ & $0,16,32,48,64$ & - \\
\hline Ozone dose (mgozone $\mathrm{mg}_{\text {antibiotics }}{ }^{-1}$ ) & $\begin{array}{c}0,5000,10,000 \\
150,000,20,000,25,000\end{array}$ & $\begin{array}{c}0,5000,10,000 \\
150,000,20,000,25,000\end{array}$ & $0,16,32,48,64,88$ & $\begin{array}{c}0,5000,10,000 \\
150,000,20,000,25,000\end{array}$ & - \\
\hline Reaction time (min) & 120 & 120 & 165 & 120 & 120 \\
\hline Mixing speed (rpm) & 200 & 200 & 200 & 200 & 200 \\
\hline Sample volume (mL) & 250 & 250 & 250 & 250 & 250 \\
\hline
\end{tabular}

${ }^{1}$ The experimental conditions for ozonation in acidic conditions. Applied ozone doses ranged from $9 \mathrm{mg}_{\text {ozone }} \mathrm{mg}_{\mathrm{TOC}}{ }^{-1}(t=15 \mathrm{~min})$ to $72 \mathrm{mg}_{\text {ozone }} \mathrm{mg}_{\mathrm{TOC}^{-1}}{ }^{-1}(t=120 \mathrm{~min})$ and from $5084 \mathrm{mg}_{\text {ozone }} \mathrm{mg}_{\text {antibiotics }}{ }^{-1}(t=30 \mathrm{~min})$ to $20,339 \mathrm{mg}_{\text {ozone }} \mathrm{mg}_{\text {antibiotics }}{ }^{-1}(t=120 \mathrm{~min}) .{ }^{2}$ The experimental conditions for ozonation in alkaline conditions. Applied ozone doses ranged from $6.8 \mathrm{mg}_{\text {ozone }} \mathrm{mg}_{\mathrm{TOC}}{ }^{-1}(t=15 \mathrm{~min})$ to $54.8 \mathrm{mg}_{\text {ozone }} \mathrm{mg}_{\mathrm{TOC}}{ }^{-1}(t=120 \mathrm{~min})$ and from $5000 \mathrm{mg}_{\text {ozone }} \mathrm{mg}_{\text {antibiotics }}{ }^{-1}(t=30 \mathrm{~min})$ to $25,000 \mathrm{mg}_{\text {ozone }} \mathrm{mg}_{\text {antibiotics }}{ }^{-1}(t=120 \mathrm{~min}){ }^{3} \mathrm{The}^{-1}$ experimental conditions for the $\mathrm{O}_{3}$ process with the addition of different $\mathrm{O}_{3}$ doses. Applied ozone doses ranged from $6.8 \mathrm{mg}_{\text {ozone }} \mathrm{mg}_{\text {TOC }}{ }^{-1}$ $(t=15 \mathrm{~min})$ to $54.8 \mathrm{mg}_{\text {ozone }} \mathrm{mg}_{\mathrm{TOC}^{-1}}{ }^{-1}(t=120 \mathrm{~min})$ and from $5000 \mathrm{mg}_{\text {ozone }} \mathrm{mg}_{\text {antibiotics }}{ }^{-1}(t=30 \mathrm{~min})$ to $25,000 \mathrm{mg}_{\text {ozone }} \mathrm{mg}_{\text {antibiotics }}{ }^{-1}$ $(t=120 \mathrm{~min}) .{ }^{4}$ The experimental conditions for ozonation in alkaline conditions with the addition of $\mathrm{H}_{2} \mathrm{O}_{2}$. Applied ozone doses ranged from $8.0 \mathrm{mg}_{\text {ozone }} \mathrm{mg}_{\mathrm{TOC}}{ }^{-1}(t=15 \mathrm{~min})$ to $64.3 \mathrm{mg}_{\text {ozone }} \mathrm{mg}_{\mathrm{TOC}^{-1}}(t=120 \mathrm{~min})$ and from $5000 \mathrm{mg}_{\text {ozone }} \mathrm{mg}_{\text {antibiotics }}{ }^{-1}(t=30 \mathrm{~min})$ to $25,000 \mathrm{mg}_{\text {ozone }} \mathrm{mg}_{\text {antibiotics }}{ }^{-1}(t=120 \mathrm{~min}) .{ }^{5}$ The experimental conditions for the $\mathrm{O}_{3}$ process with the addition of different $\mathrm{H}_{2} \mathrm{O}_{2}$ doses. 
To obtain the most efficient treatment performance, we tried different doses of $\mathrm{H}_{2} \mathrm{O}_{2}$ (Table 1, Value ${ }^{5}$ ) and different $\mathrm{O}_{3}$ doses (Table 1, Value ${ }^{3}$ ).

The working pressure was 0.5 bar and the gas flow was $30 \mathrm{~L} \mathrm{~h}^{-1}$. The experiments were carried out at room temperature $\left(20 \pm 1^{\circ} \mathrm{C}\right)$. Prior to ozonation, the $\mathrm{pH}$ of the process water was adjusted to either $\mathrm{pH} 3.70 \pm 0.10$ or $\mathrm{pH} 10.85 \pm 0.10$ by adding sulfuric acid $\left(\mathrm{H}_{2} \mathrm{SO}_{4}\right)$ or sodium hydroxide $(\mathrm{NaOH})$. Hydrogen peroxide $(30 \%$, Ph.Eur., USP, pharma grade, Applichem, Darmstadt, Germany) was dosed into the system at the beginning of the experiment, to combine $\mathrm{O}_{3}$ with $\mathrm{H}_{2} \mathrm{O}_{2}$.

\subsection{Analytical Procedure}

4.4.1. High-Performance Liquid Chromatography Combined with Mass Spectrometry (HPLC/MS)

We wanted to develop a method that would identify CIP and AMX simultaneously. The content of both in the wastewater was determined by liquid chromatography combined with tandem mass spectrometry (LC/MS/MS). The method proved to be highly selective and highly sensitive. To develop the method, antibiotic standard solutions were prepared and injected directly into the mass spectrometer (AB Sciex API 2000, SCIEX, Framingham, MA, USA). We also optimized the conditions at the mass detector (ionization, capillary tension, source temperature, and collision energy). During optimization, we tended to obtain the most intense reaction for both base and fragment ionization.

For the optimization of the MS detector, we optimized the following parameters (as shown in Table 2): DP (Declustering Potential), CE (Collision Energy), and CXP (Collision Cell Exit Potential).

Table 2. Optimization parameters DP, CE, CXP for standards.

\begin{tabular}{ccccc}
\hline Compound & Transition & DP (V) & CE (V) & CXP (V) \\
\hline Ciprofloxacin & $332.16 / 231.2$ & 56 & 51 & 4 \\
Ciprofloxacin & $332.16 / 288.2$ & 56 & 23 & 4 \\
Amoxicillin & $366.171 / 114.1$ & 31 & 25 & 0 \\
Amoxicillin & $366.171 / 208.2$ & 31 & 19 & 4 \\
\hline
\end{tabular}

The selected antibiotics were then analyzed using a $50 \mathrm{~mm} \times 2.0 \mathrm{~mm}$ Synergy FusionRP column with $2.5 \mu \mathrm{m}$ particle size (Phenomenex, Aschaffenburg, Germany). The following mobile phase gradient was used with Solvent A $(95 / 5 / 0.2, v / v / v$; a mixture of ultrapure water, acetonitrile, and formic acid) and Solvent B (50/50/0.2, v/v/v; a mixture of methanol, acetonitrile, and formic acid). The gradient was as follows: $0 \mathrm{~min}, 0 \% \mathrm{~B} ; 2 \mathrm{~min}$, $0 \% \mathrm{~B} ; 7 \mathrm{~min}, 100 \% \mathrm{~B} ; 7.10$, min $0 \% \mathrm{~B}$; and $17 \mathrm{~min}, 0 \% \mathrm{~B}$. The solvents were pumped through the column at a flow rate of $300 \mu \mathrm{L} \mathrm{min}{ }^{-1}$. The injection volume was $50 \mu \mathrm{L}$ and the column temperature was maintained at $40^{\circ} \mathrm{C}$. The LC/MS/MS method and all optimizations were performed using a pure solution of AMX and CIP at a concentration of $200 \mathrm{ng} \mathrm{mL}^{-1}$ in a solvent of $0.1 \%$ formic acid in a mixture of $\mathrm{CH}_{3} \mathrm{OH}: \mathrm{CH}_{3} \mathrm{CN}$ (1:1). Chromatograms were also recorded at a flow rate of $300 \mu \mathrm{L} \mathrm{min}^{-1}$ using two other columns: ASCENTIS Express C18 $(50 \mathrm{~mm} \times 2.1 \mathrm{~mm}$ I.D., $2.7 \mu \mathrm{m})$ and Kinetex XB-C18 100 A $(50 \mathrm{~mm} \times 2.1 \mathrm{~mm}$ I.D., $2.6 \mu \mathrm{m})$

The model wastewater samples were prepared in replicates. AMX and CIP were spiked at $850 \mathrm{ng} \mathrm{mL}^{-1}$ because the quantification limits in the municipal and heavily contaminated hospital wastewater samples were higher and the linearity ranges were different. For quality control, an external 6-point calibration curve in the range $40 \mathrm{ng} \mathrm{mL}^{-1}-800 \mathrm{ng} \mathrm{mL}^{-1}$ was constructed and measured with the assay samples. The squared coefficient of determination for selected compounds was determined by the quadratic regression of the calibration curves $\left(\mathrm{r}^{2}>0.99\right)$.

The extraction efficiency of the selected antibiotics was tested on three different SPE cartridges: Varian Bond Elut Plexa, $60 \mathrm{mg} / 3 \mathrm{~mL}$; Oasis HLB, $200 \mathrm{mg} / 6 \mathrm{~mL}$; and Supelco HLB Select, $60 \mathrm{mg} / 3 \mathrm{~mL}$. 
Solid phase extraction was then performed using the Oasis HLB $200 \mathrm{mg}$ column. The procedure was as follows: $200 \mathrm{~mL}$ of the wastewater sample was adjusted to $\mathrm{pH} 8$ (with $\left.0.05 \mathrm{M} \mathrm{NH}_{4} \mathrm{OH}\right)$ and $10 \mu \mathrm{L}$ ISTD MIX $2\left(\mathrm{c}=200 \mathrm{ng} \mathrm{mL}^{-1}\right)$ was added.

Conditioning of the selected Oasis HLB $200 \mathrm{mg}$ cartridge was performed by first passing three volumes of $\mathrm{MeOH}$ and three volumes of Mili-Q water (which was previously adjusted to $\mathrm{pH}$ 8) through the column. The prepared wastewater sample was loaded onto the SPE cartridge at a flow rate of $3 \mathrm{~mL} \mathrm{~min}^{-1}$, then washed with $10 \mathrm{~mL}$ of $10 \% \mathrm{MeOH}$ in water and dried with a gentle stream of air. Finally, elution was performed with two volumes of $\mathrm{MeOH}$. The extracts were collected in $10 \mathrm{~mL}$ plastic tubes. The eluate was then concentrated to approximately $300 \mu \mathrm{L}$ under a gentle air flow. The samples were then made up to $1 \mathrm{~mL}$ in a test tube containing a solvent consisting of Mili-Q water and a 95:5 mixture of methanol and acetonitrile. Finally, the samples were centrifuged at $4000 \mathrm{rpm}$ for $10 \mathrm{~min}$.

\subsubsection{TOC Determination}

To monitor the ozonation efficiency of the selected antibiotics in the model effluent, TOC concentrations $\left(\mathrm{mg} \mathrm{L}^{-1}\right)$ were determined according to DIN EN 1484 [43] using Shimadzu TOC 5000A analyzer (Shimadzu, Kyoto, Japan).

\subsection{Toxicity Assays}

In order to assess the residual toxicity of the treated wastewater, the inhibition of oxygen consumption by nitrifying and heterotrophic microorganisms in the activated sludge was measured according to ISO 8192:2007 [28]. Activated sludge consumes oxygen through the degradation of added readily biodegradable substances (peptone). If the wastewater contains toxic substances, the oxygen consumption rate is reduced. The activated sludge for the test was taken from a wastewater treatment plant treating mostly domestic wastewater $(350,000 \mathrm{PE})$. The sludge was washed three times with tap water to remove organic substrate from the wastewater. Then, the activated sludge was aerated and stirred for $24 \mathrm{~h}$. The concentration of the activated sludge was determined by filtering through filter paper and drying at $105^{\circ} \mathrm{C}$ to constant mass. In the toxicity test, an appropriate amount (mL) of the sludge was added to achieve a concentration of $1500 \mathrm{~g}_{\mathrm{MLVSS}} \mathrm{L}^{-1}$. Different mixtures were prepared: (i) $70 \mathrm{vol} . \%$ of the model wastewater containing $1.2 \mathrm{mg} \mathrm{L}^{-1}$ antibiotics, (ii) 70 vol.\% of the ozone treated model wastewater, and (iii) test system without the sample (blank).

Oxygen consumption rates were calculated from the measured oxygen concentrations $\left(\mathrm{mg}_{\text {oxygen }} \mathrm{L}^{-1}\right)$ as a function of time $(30 \mathrm{~min})$ using a CellOx 325 oxygen electrode (WTW a xylem brand, Xylem Inc., New York, NY, USA). The oxygen consumption rates of the samples were compared with the blank sample to determine the inhibition of oxygen consumption (\%).

The blank sample and the model wastewater samples were continuously aerated on a magnetic stirrer (RH DW Ika, Staufen, Germany) for $30 \mathrm{~min}$. After $30 \mathrm{~min}$, each mixture was transferred to the closed $300 \mathrm{~mL}$ oxygen bottle. Over $6 \mathrm{~min}$, the dissolved oxygen concentration was measured at $30 \mathrm{~s}$ intervals using the oxygen electrode. The abiotic sample was aerated without the addition of activated sludge. The inhibition test was performed at a temperature of $20 \pm 2{ }^{\circ} \mathrm{C}$.

\section{Conclusions}

In the last decade, antibiotics have been found in many aquatic ecosystems, causing various adverse effects on aquatic organisms. To protect the environment and human health, their introduction into the environment should be avoided. One of the ways to do this is to improve biological wastewater treatment by adding an additional stage that would ensure more efficient treatment. The present study has shown that CIP and AMX can be successfully removed by ozonation (at a dosage of $100 \mathrm{mg} \mathrm{L}^{-1}$ ) under alkaline conditions. Removal efficiencies were $99 \%$ for AMX and $96 \%$ for CIP, but some degradation products remained, as confirmed by TOC analyses. The addition of $\mathrm{H}_{2} \mathrm{O}_{2}$ slightly increased the 
TOC removal efficiency, although the overall amount of antibiotic removal remained the same as without addition. The results also showed that the toxicity of the activated sludge to heterotrophic and nitrifying microorganisms of the activated sludge was significantly reduced by ozonation, so further biological treatment could be considered. The addition of hydrogen peroxide improved the process. Therefore, ozonation is a promising technique for reducing the toxicity of wastewater containing persistent antibiotics that are difficult to biodegrade and could be used in the pretreatment system before the conventional biological treatment plant.

Author Contributions: Conceptualization, S.Š.T.; methodology, A.Ž.G. and M.K.; software, K.P.; validation, A.Ž.G., M.K. and K.P.; formal analysis, S.A.; investigation, S.A.; resources, S.Š.T.; K.P. and A.Ž.G.; data curation, S.Š.T.; writing-original draft preparation, S.A.; writing-review and editing, S.Š.T.; A.Ž.G. and M.K.; visualization, M.K.; supervision, S.Š.T., A.Ž.G. and M.K.; project administration, S.Š.T.; funding acquisition, S.Š.T. All authors have read and agreed to the published version of the manuscript.

Funding: This research was funded by the Slovenian Research Agency ARRS, grant number 1604-003, and the National Research Programme Textile Chemistry (P2-0118), Chemical Engineering (P2-0191), and Analytical Chemistry (P1-0153).

Institutional Review Board Statement: Not applicable.

Data Availability Statement: Not applicable.

Conflicts of Interest: The authors declare no conflict of interest.

\section{References}

1. Yaghmaeian, K.; Moussavi, G.; Alahabadi, A. Removal of Amoxicillin from contaminated water using $\mathrm{NH}_{4} \mathrm{Cl}_{\text {-activated carbon: }}$ Continuous flow fixed-bed adsorption and catalytic ozonation regeneration. Chem. Eng. J. 2014, 236, 538-544. [CrossRef]

2. Zuccato, E.; Castiglioni, S.; Bagnati, R.; Melis, M.; Fanelli, R. Source, occurrence and fate of antibiotics in Italian aquatic environment. J. Hazard. Mater. 2010, 179, 1042-1048. [CrossRef]

3. Batt, A.L.; Sungpyo, K.; Aga, D.S. Comparison of the occurrence of antibiotics in four full-scale wastewater treatment plants with varying designs and operations. Chemosphere 2007, 68, 428-435. [CrossRef]

4. Dodd, M.C.; Buffle, M.O.; Von Gunten, U. Oxidation of antibacterial molecules by aqueous ozone: Moiety-specific reaction kinetics and application to ozone based wastewater treatment. Environ. Sci. Technol. 2006, 40, 1969-1977. [CrossRef]

5. Daoud, F.; Pelzer, D.; Zuehlke, S.; Spiteller, M.; Kayser, O. Ozone pretreatment of process wastewater generated in course of fluoroquinolone production. Chemosphere 2017, 185, 953-963. [CrossRef] [PubMed]

6. Hom-Diaz, A.; Norvill, Z.N.; Blánquez, P.; Vicent, T.; Guieysee, B. Ciprofloxacin removal during secondary domestic wastewater treatment in high rate algal ponds. Chemosphere 2017, 180, 33-41. [CrossRef]

7. Enick, O.V.; Moore, M.M. Assessing the assessments: Pharmaceuticals in the Environment. Environ. Impact Assess. Rev. 2007, 27, 707-729. [CrossRef]

8. Jelic, A.; Gros, M.; Ginebreda, A.; Cespedes-Sánchez, R.; Ventur, F.; Petrovic, M.; Barcelo, D. Occurrence, partition and removal of pharmaceuticals in sewage water and sludge during wastewater treatment. Water Res. 2011, 45, 1165-1176. [CrossRef] [PubMed]

9. Genç, N.; Can-Doğan, E.; Yurtsever, M. Bentonite for Ciprofloxacin removal from aqueous solution. Water Sci. Technol. 2013, 68, 848-855. [CrossRef]

10. Andreozzi, R.; Canterino, M.; Marotta, R.; Paxéus, N. Antibiotic Removal from Wastewater: The Ozonation of Amoxicillin. J. Hazard. Mater. 2015, 122, 243-250. [CrossRef] [PubMed]

11. Buxton, G.U.; Greenstock, C.L.; Helman, W.C.; Ross, A.B. Critical review of rate constant for reactions of hydrated electrons, hydrogen atoms and hydroxyl radicals $(\mathrm{HO} / \mathrm{O})$ in aqueous solution. J. Phys. Chem. Ref. Data 1988, 17, 513-886. [CrossRef]

12. Umar, M.; Roddick, F.; Fan, L.; Aziz, H.A. Application of ozone for the removal of bisphenol A from water and wastewater-A review. Chemosphere 2013, 90, 2197-2207. [CrossRef]

13. Sedlak, D.L.; Pinkston, K.E. Factors affecting the concentrations of pharmaceuticals released to the aquatic environment. Water Res. 2001, 120, 56-64.

14. Huang, C.H.; Renew, J.E.; Smeby, K.L.; Pinkerston, K.; Sedlak, D.L. Assessment of potential antibiotic contaminants in water and preliminary occurrence analysis. J. Contemp. Water Res. Educ. 2001, 120, 30-40.

15. Lange, F.; Cornelissen, S.; Kubac, D.; Sein, M.M.; Von Sonntag, J.; Hannich, C.B.; Golloch, A.; Heipieper, H.J.; Moder, M.; Von Sonntag, C. Degradation of macrolide antibiotics by ozone: A mechanistic case study with clarithromycin. Chemosphere 2016, 65, 17-23. [CrossRef] [PubMed]

16. Michael, I.; Rizzo, L.; McArdell, C.S.; Manaia, C.M.; Merlin, C.; Schwartz, T.; Dagot, C.; Kassinos, F.D. Urban wastewater treatment plants as hotspots for the release of antibiotics in the environment: A review. Water Res. 2013, 47, 957-995. [CrossRef] [PubMed] 
17. Homem, V.; Santos, L. Degradation and removal methods of antibiotics from aqueous matrices: A review. J. Environ. Econ. Manag. 2011, 92, 2304-2347. [CrossRef]

18. Kumar, M.S.; Saha, A.K.; Sinha, A. Removal of Ciprofloxacin using modified advanced oxidation processes: Kinetics, pathways and process optimization. J. Clean. Prod. 2018, 171, 1203-1214.

19. Zhu, L.; Schübel, B.S.; Xiao, H.; Hollert, H.; Kueppers, S. Electrochemical oxidation of fluoroquinolone antibiotics: Mechanism, residual antibacterial activity and toxicity change. Water Res. 2016, 102, 52-62. [CrossRef]

20. Hernandez, R.; Zappi, M.; Colluci, J.; Jones, R. Comparing the performance of various advanced oxidation process for treatment of acetone contaminated water. J. Hazard. Mater. 2002, 92, 33-50. [CrossRef]

21. Zhao, Y.; Kuang, J.; Zhang, S.; Li, X.; Wang, B.; Huang, J.; Deng, S.; Wang, Y.; Yu, G. Ozonation of indomethacin: Kinetics, mechanisms and toxicity. J. Hazard. Mater. 2017, 323, 460-470. [CrossRef]

22. Phoon, B.L.; Ong, C.C.; Saheed, M.S.M.; Show, P.L.; Ling, T.C.; Lam, S.S.; Juan, J.C. Conventional and emerging technologies of removal antibiotics from wastewater. J. Hazard. Mater. 2020, 400, 122961. [CrossRef]

23. Cai, Q.Q.; Jothinathan, L.; Deng, S.H.; Ong, S.L.; Ng, H.Y.; Hu, J.Y. 11-Fenton and ozone-based AOP processes for industrial effluent treatment. In Advanced Oxidation Processes for Effluent Treatment Plant; Elsevier: Amsterdam, The Netherlands, 2021; pp. 199-254.

24. Akbari, M.Z.; Xu, Y.; Lu, Z.; Peng, L. Review of antibiotics treatment by advance oxidation processes. Environ. Adv. 2021, 5, 100111. [CrossRef]

25. Anjali, R.; Shanthakumar, S. Insights on the current status of occurrence and removal of antibiotics in wastewater by advanced oxidation processes. J. Environ. Manag. 2019, 246, 51-62. [CrossRef] [PubMed]

26. Wang, J.; Zhuan, R. Degradation of antibiotics by advanced oxidation processes: An overview. Sci. Total Environ. 2020, 701, 135023. [CrossRef]

27. Stavbar, S.; Knez-Hrnčič, M.; Premzl, K.; Kolar, M.; Šostar-Turk, S. Sub- and super-critical water oxidation of wastewater containing Amoxicillin and Ciprofloxacin. J. Supercrit. Fluids 2017, 128, 73-78. [CrossRef]

28. International Organization for Standardization. Water Quality-Test for Inhibition of Oxygen Consumption by Activated Sludge for Carbonaceous and Ammonium Oxidation; ISO 8192:2007; European Committee for Standardization: Brussels, Belgium, 2015.

29. Baker, D.R.; Kasprzyk-Hordern, B. Multi-residue analysis of drugs of abuse in wastewater and surface water by solid-phase extraction and liquid chromatography-positive electrospray ionisation tandem mass spectrometry. J. Chromatogr. A 2011, 1218, 1620-1631. [CrossRef]

30. Rossmann, J.; Schubert, S.; Gurke, R.; Oertel, R. Simultaneous determination of most prescribed antibiotics in multiple urban wastewater by SPE-LC-MS/MS. J. Chromatogr. B 2014, 969, 162-170. [CrossRef] [PubMed]

31. Gurke, R.; Rossmann, J.; Schubert, S.; Sandmann, T.; Rößler, M.; Oertel, R.; Fauler, J. Development of a SPE-HPLC-MS/MS method for the determination of most prescribed pharmaceuticals and related metabolites in urban sewage samples. J. Chromatogr. B Analyt. Technol. Biomed. Life Sci. 2015, 990, 23-30. [CrossRef]

32. Hallind-SØrensen, B.; Nors-Nielsen, S.; Lanzky, P.F.; Ingerslev, F.; Holten-LützhØft, H.C.; JØrgensen, S.E. Occurrence, fate and effects of pharmaceutical substances in the environment-A review. Chemosphere 1997, 36, 357-393. [CrossRef]

33. Kamilla, M.S.; Hansen, A.S.; Ravi, K.C.; Mònica, E.C.; Kai, B.; Henrik, R.A. Ozonation for source treatment of pharmaceuticals in hospital wastewater-Ozone lifetime and required ozone dose. Chem. Eng. J. 2016, 290, 507-514.

34. Kurt, A.; Merl, B.K.; Özengin, N.; Sivrioğlu, Ö.; Yonar, T. Treatment of Antibiotics in Wastewater Using Advanced Oxidation Processes (AOPs). In Physico-Chemical Wastewater Treatment and Resource Recovery; Robina Farooq and Zaki Ahmad, IntechOpen: London, UK, 2017.

35. Litter, M.I. Introduction to photochemical advanced oxidation processes for water treatment. Environ. Photochem. Part II 2005, $2,325-326$.

36. Akmehmet, I.B.; Ötker, M. Treatment of pharmaceutical wastewater containing antibiotics by $\mathrm{O}_{3}$ and $\mathrm{O}_{3} / \mathrm{H}_{2} \mathrm{O}_{2}$ processes. Chemosphere 2003, 50, 85-95. [CrossRef]

37. Demeestere, K.; De-Witte, B.; Dewulf, J.; Van-Langehove, H. Advanced oxidation of fluoroquinolone antibiotics in water by ozone and the peroxone process: Mechanisms, kinetics and antibacterial activity. In Proceedings of the 1st International Conference on Photocatalytic and Advanced Oxidation Technologies for Treatment of Water, Air, Soil and Surfaces, Gdansk, Poland, 4-8 July 2011; pp. 81-82.

38. Najafpoor, A.A.; Sani, O.N.; Alidadi, H.; Dehghan, A.; Moheb-Seraj, S.A. Ciprofloxacin removal by Ozonation from aqueous solutions. Int. J. Environ. Health Res. 2017, 2, 116-125.

39. Lefebvre, O.; Shi, X.; Tein, J.G.; Ng, H.Y. Suitability of ozone pre-treatment of Amoxicillin wastewater. Water Sci. Technol. 2013, 68, 2492-2496. [CrossRef]

40. De-Witte, B.; Van-Langenhove, H.; Demeestere, K.; Dewispelaere, P.; Dewulf, J. Ciprofloxacin ozonation in hospital wastewater treatment plant effluent: Effect of $\mathrm{pH}$ and $\mathrm{H}_{2} \mathrm{O}_{2}$. Chemospehe 2010, 78, 1142-1147. [CrossRef]

41. Zaviska, F.; Drogui, P.; Mercier, G.; Blais, J.F. Advanced oxidation processes for waters and wastewaters treatment: Application to degradation of refractory pollutants. Crit. Rev. Environ. Sci. Technol. 2009, 22, 535-564.

42. Mokrini, M.; Oussi, D.; Esplugas, S. Oxidation of aromatic compounds with UV radiation/ozone/hydrogen peroxide. Water Sci. Technol. 1997, 35, 95-102. [CrossRef]

43. German Institute for Standardisation. Water Analysis-Guidelines for the Determination of Total Organic Carbon (TOC) and Dissolved Organic Carbon (DOC); DIN EN 1484; Deutsches Institut für Normung e. V.: Berlin, Germany, 1997. 